\title{
LIFTING OF WATER BY THERMODYNAMIC PUMP
}

\author{
By بواس \\ A.A. EL-HADrk
Aggociate Professor, Mechanical Power Enginesing \\ Faculty of Engineering, University of Al-Mansourah \\ Al-Mansourah, \\ Egypt
}
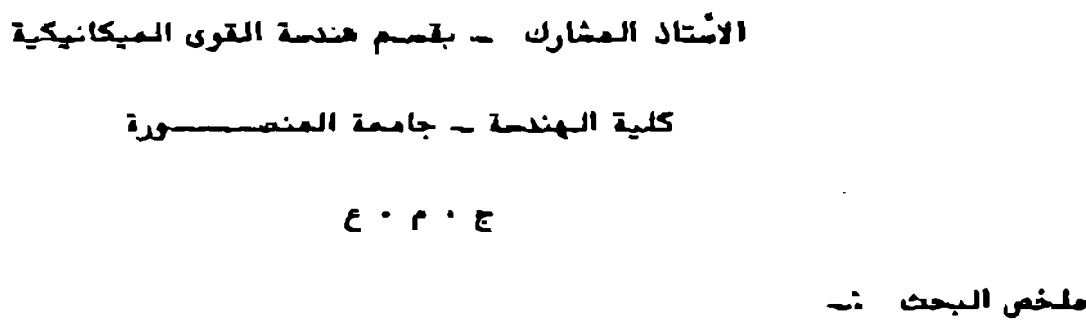

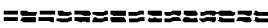

يتتاول مدا البحث اماكنية رنع المياه من بئر مياه جونيه مستوى المياه بـ أتل من مستــوى

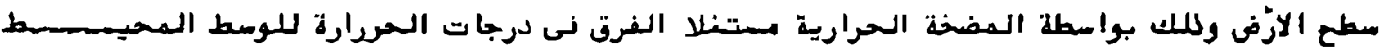

داخل البالون يوضع هواء ومن حوله فريون - 11 • وأثنا، النهار يتبخر اللغرين ويضفط على الهواء

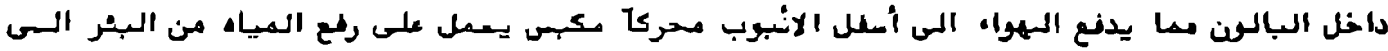
أعلى سطح الارٔض - وتد تم تصميم مضغة حرارية تعمل على ثغس إلأعلوب وتم كللك تياس معدل رمع

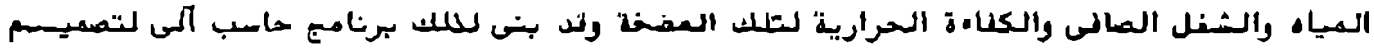

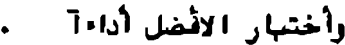

\section{Abstract}

This paper invertigates the feasibility of pumping up water from a water well uging a temperature difference in the enviroment. A device usable for water lifting is the hoat proseure pump. The evaporator-condeneer cycle will expand and comprese the air inside a flexible balloon which will drive water from the well to a higher level as reguired. It is proposed to bulld several heat pumpo with different designe and measure the thermal efficiencies of each type. A parametric experimental program will be run on each design and the optimum conditions and dealgn conflguration will be examined. 
Nomenclature:

$\begin{array}{lll}\mathrm{T}_{\mathbf{H}} & \text { Hot sources temperature } & \mathrm{K} \\ \mathrm{T}_{\mathbf{c}} & \text { Cold sink temperature } & \mathrm{K} \\ \Delta \mathrm{T} & \text { Temperature difference } & \mathrm{K} \\ \mathbf{Z} & \text { Height } & \mathrm{m} \\ \mathrm{m} & \text { The Elow rate of water } & \text { litre }\end{array}$

Introduction:

Much attention and continuous efforts have been paid for long to obtain plain water in Middle-East desert area. Desalination has been a modern solution for this problem and as a matter of fact, the desalination capacity has been steadily increased with demand. However, the traditional method of obtaining brackish water from underground well is still practiced and, in fact, many of agriculture work depend on the water from underground.

The idea of obtaining water from a water well without utilizing any form of fuel or electric power seems very attractive, especially in remote areas where transmission lines do not exist. This project suggests an idea where water can be pumped from a water well only using a temperature difference in the environment. The temperature difference can be that between a solar collector and a cold water obtained freah from the well. The temperature difference is first converted into vapour pressure difference of an auxiliary fluid and then converted into mechanical energy. to lift the water.

Figure 1, shows a schematic diagram of a pump, which consists of a pump chamber 1 with a balloon 2 in it, a tank placed in a well 5, non-return valve 6 , and connecting piping. Pipeline 3 connects balloon 2 and canister 5 . Another pipeline 7 goes straight up from the bottom of canister 6 to the ground. In pump chamber 1 , air enclosed in balloon 2 and a working fluid such as Freon 11 is outside the balloon. The working fluid is condensed at night and vapourized in the daytime. At night the chamber pressure is low so that the balloon is inflated with the air. When temperature rises in the daytime the high pressure vapour of the working fluid squeezes balloon 2; the compresses air, through pipeline 3, to the water in canister 6 and raises it up through pipeline 8 to the ground. When environmental temperature drops at night, the chamber pressure becomes low so that water in well 5 flows into canister 6 through non-5eturn valve, and the balloon is again inflated with the air. Water is, therefore, raised from the well to the ground, once a day. 


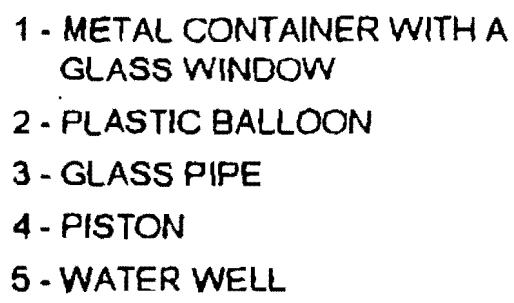

1. METAL CONTAINER WITHA GLASS WINDOW

2. PLASTIC BALLOON

3 - GLASS PIPE

4 - PISTON

5 - WATER WELL

6 - CANISTER WITH NON RETURN VALVE

7 - WATER LIFT PIPE

B - NON - RETURN VALVE

9 - WATER TANK

10. GROUND

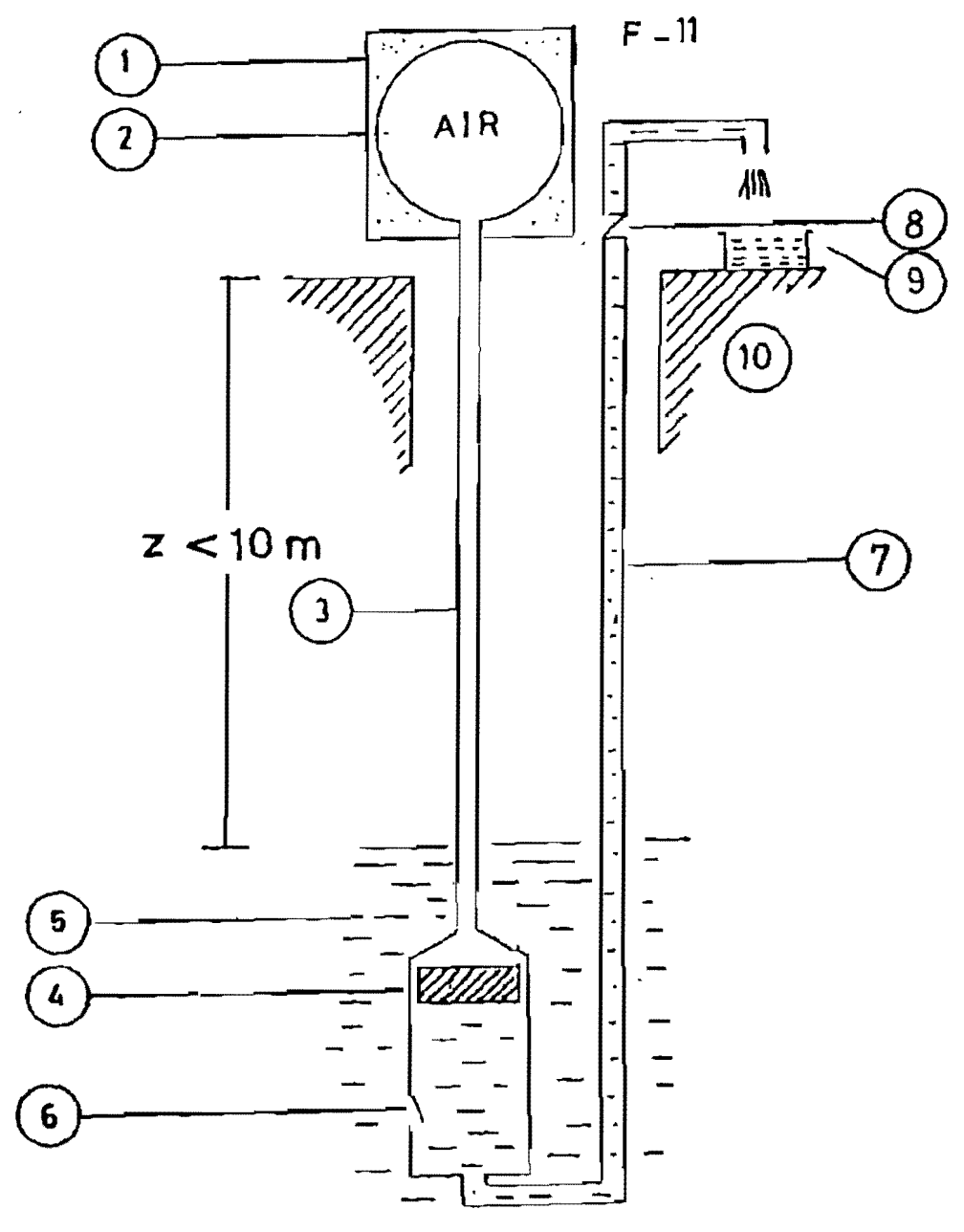

Figure 1. Schemalic diagram of an air-balloon type heat-pressure pump, operaled once a day lor heads larger than $7 \ln$. 
1 - METAL CONTAINER WITH A GLASS WINDOW

2 - PLASTIC BALLOON

3 - NON - RETURN VALVE

4- WATER LIFT PIPE
6. NON - RETURN VALVE

7 - WATER TANK

8 - WATER WELL

9 - GROUND

1

2

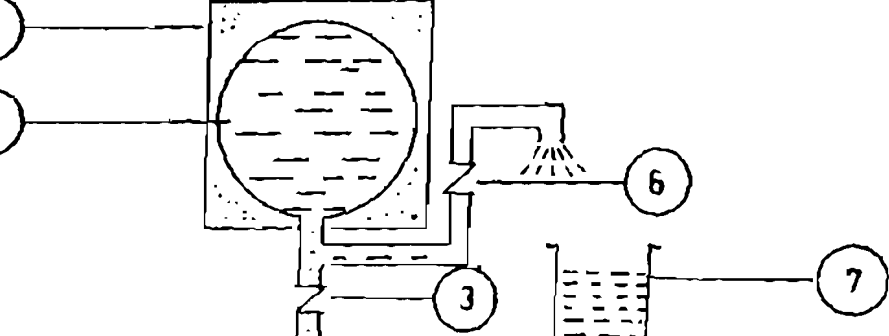

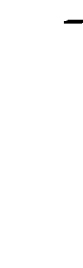

$z<10 m$

9

(4)

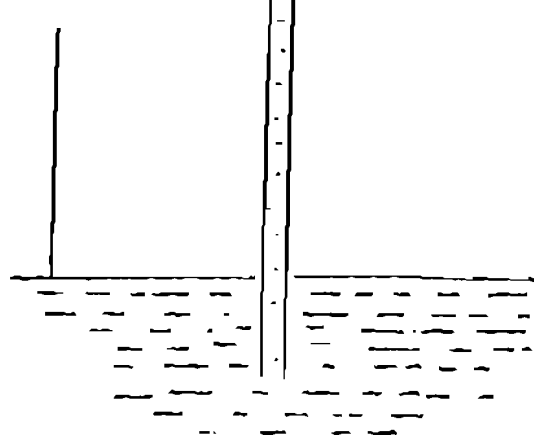

Flgure 2. Schemalic diagram of water-balloon type heat-pressure pump. operated once a day for heads below $10 \mathrm{~m}$. 
If the water level in the well is not more than 10 meters deep from the pump chamber, a balloon can suck up the water directly from the well. As outlined in Figure 2, a pump chamber with a single pipe extending from the chamber to the well can be used for this purpose. When the chamber pressure becomes low at night, water from the well flows into the balloon through a nonreturn valve. In the daytime the balloon pressure becomes high so that the water-filled balloon is gqueezed and then the water is pushed out, through another return valve, to the ground.

The heat-pressure pumps shown in Figures 1 and 2 , work only once a day. The purpose of this research proposal is to design and build an apparatus which may pump up an underground water to the ground level all through the daytime. A temperature difference between the Sun's heat received on the ground and the cold underground water itself can be used as the driving force of continuously operating heat-pressure pumps. Also, choosing of balloon materials and some other pumping systems such as of the piston-type, heat-presoure pumps performance will be considered. It is desired to establish the design details of a heat pressure pump system to lift up water from a deep water well to be used in the desert, optimize of the operating conditions to drive such a heat pressure pump in practice, and compare the different design schemes, have been carried out.

\section{Methodology:}

The plan of work is shown in the flow chart of Figure 3.

\section{Definition of parameters:}

1. Type of refrigerant: Variety of refrigerants will be tested starting from Freon 11.

2. Temperature difference for the heat pump ( $\Delta T)$. This is the temperature difference between the hot source $\left(T_{H}\right)$ and cold source $\left(T_{C}\right)$. In practlce, however, cold water from a well could be used as a cooling sink and a solar boiler could be used as a heating source.

3. The height $z$ attainable at a certain temperature difference $(\Delta \mathrm{T})$.

4. The flow rate of water obtained $(\dot{m})$ as output at given height (1itre/cycle).

An example of an actual heat-pressure pump with its construction details and preliminary results is given below. 


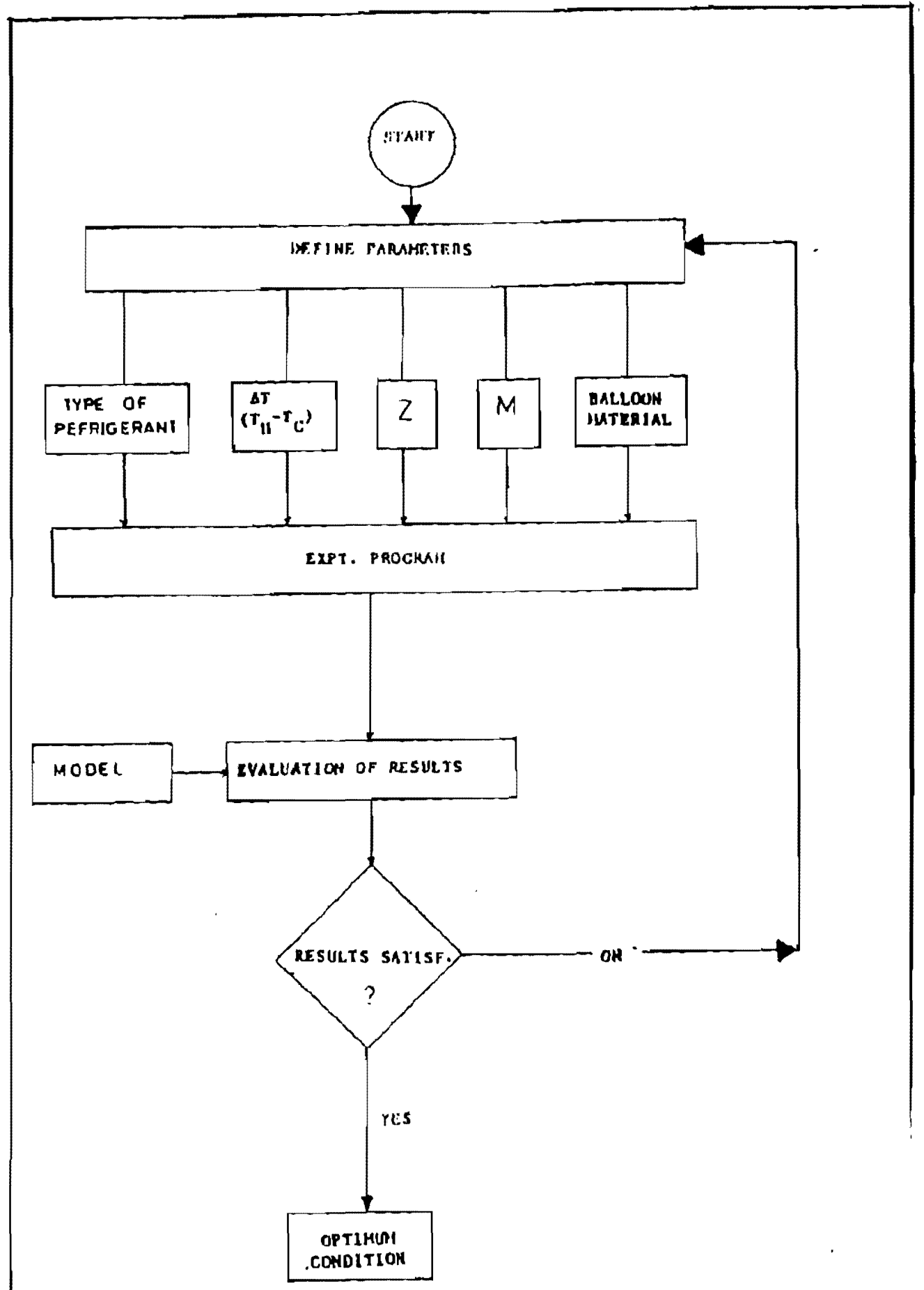

FIGURE. 3. Flov Chert of the Project 


\section{Rreliminary Lab. Results:}

A lab test apparatus was built in Kuwait Technological College as shown in Figure 4.

\section{The apparatus specifications were:}

Balloon volume

Chamber volume

Refrigerant used

Hot water temperature

Cold water temperature

Submerged tank volume

Elevation of upper delivery tank

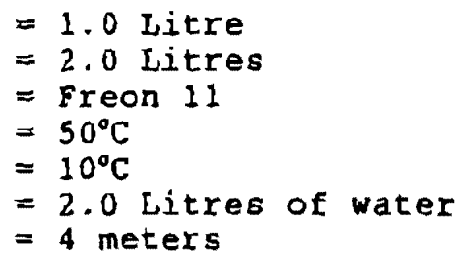

Under these experimental conditions an average rate of 0.31 litres/min. of water was pumped into the upper delivery tank. This result is positive indication of the potential usage of such pump.

The apparatus was operated by switching on the heat cycle using the solenoid valves. Heat will vapourize Freon 11 in the container (1) and this squeezes the air-filled balloon (2). The compressed air thus produces the pressure on the water in tank (5) and lift the water through pipe (6) to the upper tank (7), when the container (1) is cooled, the balloon (2) in again inflated with the aix and water in the well flows into the tank (5) through the non-return valve installed.

The heat pressure pump shown in Figure 5 is the one which is going to build in the first phase of this research. This pump consists of a pumping chamber, a boiler and a condenser. The pumpe shown in Figures 1,2 and 4 are consisted of a single chamber which acts as a boiler, condenser, or a punping chamber. Therefore, the single chamber pump has a low thermal efficiency. The pump shown in Figure 5, however, expected to improve the efficiency considerably.

With the heat-pressure pump of Figure 5 , examinations are made experimentally on water lift rate, pump power as a function of hot water temperature, cold water temperature and depth of water level. The thermal efficiency of such pump will be examined.

The second and the final phase to be built is a heatpressure pump with two balloons, as shown in Figure 6 . The following parameters will then be studied.

1. Selection of refrigerant suitable for the environmental conditions: high temperature obtainable in a boiler installed in the ground level, temperature of underground cold water and deptb of water level from the ground. Also, possibility of using mixture of refrigerants is examined. 
M. 111 A.A. El-Hadik

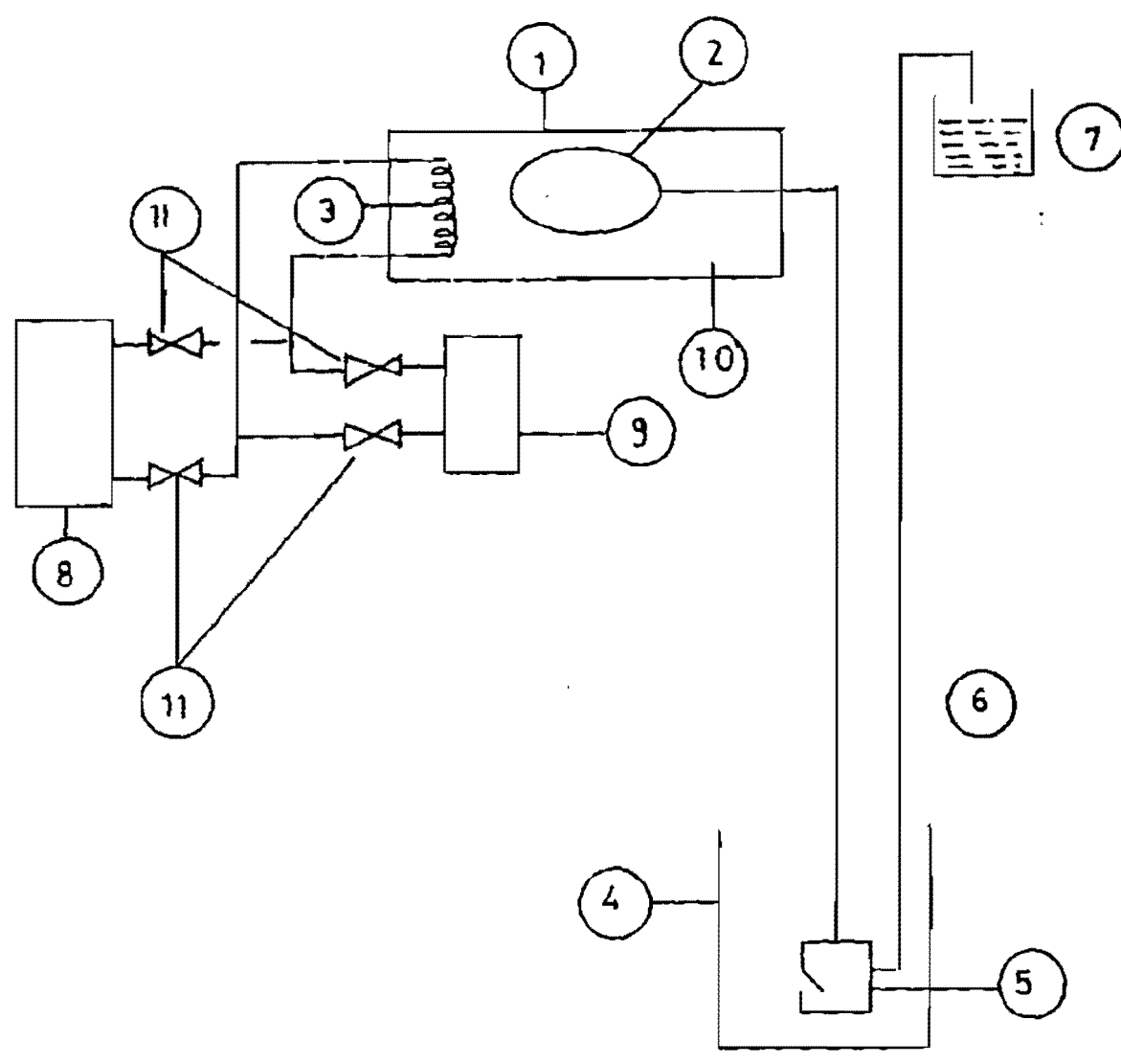

Fig. 4: A Heat-pressure pump Constructed at kuwait college of Technological studies.

1. Metal container With a Glass Window

2. Plastic Balloon

3. Coll for Heating or Cooling

4. Water Tank

5. C nister with non-return valve

6. Water lift Pipe

7. Collected Water

8. Cooler (Cold Water $10^{\circ} \mathrm{C}$ )

9. Boiler (hot Water $50^{\circ} \mathrm{C}$ )

10. Preon 11

11. Solenoid values 
Mansoura Eegineering Journal (M.E.J), Vol. 20, No.2, June 1995 14.112

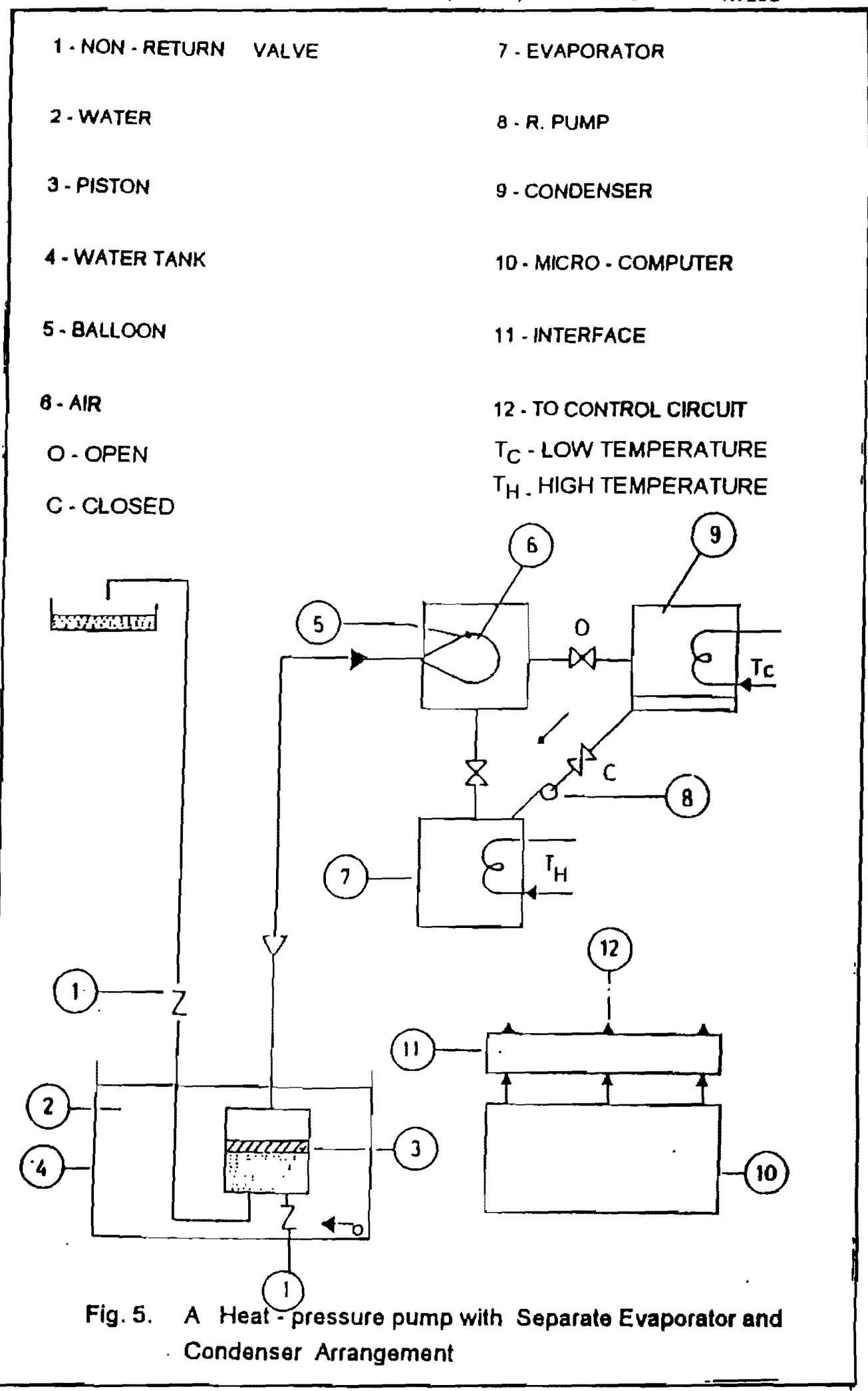


M. 113 A. A. E1-Hadik

1 - CONDENSER

2 - R. PUMP

3 - PUMPING CHAMBERS

4 - WARM WATER

5 - EVAPORATOR
6 - COLD WATER

7. MICRO - COMPUTER

8. INTERFACE

9. TO CONTROL CIRCUT

C - Closed

O - OPEN

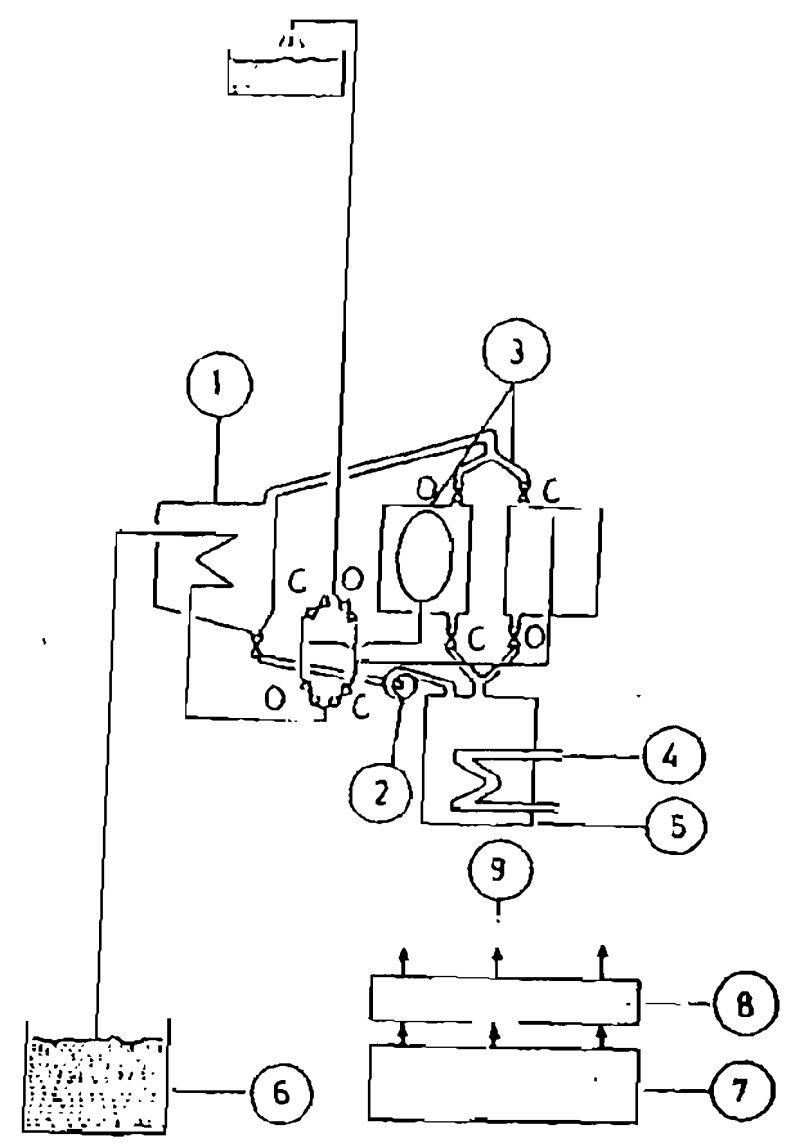

Fig. 6. Heal Pressure pump for Conlinuous Operatlon. 
2. A small amount of auxiliary power is needed for switch operation, for lifting water in and out of the balloons and for introducing refrigerant vapour in and out of the pumping chamber. Study will be made to perform the switch operation mechanically by a pressure difference between the two punping chambers. So no electric power of any small amount will be needed for the operation of the heat-pressure pump.

3. Thermal efficiency of the boiler and that of the whole heatpreasure pump.

4. Selection of proper material for the balloons for prolonged operation.

5. A mathematical model may be developed, based on the lab scale experiments. This will assist the design of a pilot scale heat-pressure pump.

6. Plastic balloon might be replaced at a later stage of the research by a piston-like motion, if a lubricating refrigerant could be found.

Details of Experimental program:

1. Run parametric experimental study on the pumps shown in Figures 5 and 6 . This will include:

1.1 Maximum height gained at different evaporator temperature $\mathrm{T}_{\mathrm{H}}$ and fixed condenser temperature $\mathrm{T}_{C}$.

1.2 Thermal efficiency of boiler and condenser.

1.3 Amount of water collected at different boiler temperatures and different condenser temperatures as a function of water depth.

1.4 Effect of refrigerant used.

1.5 Efficiency of the whole pump units.

2. Run parametric experimental study on the pumps. The pump operation will be fully automated and will be controlled by microcomputer, on which data will be processed as well.

3. We are not sure at this stage if we can find lubricating refrigerant. If we do, a piston-like mechanism will be tried and used instead of the balloons.

Solar energy, in the form of heat, is particularly suited to small scale (less than a few kw) pumping applications. unlike most energy uses water pumping for irrigation purposes does not require continuity of supply. There are numerous methods by which heat can be converted to pumping power. Some of these are well 
developed and others are new and being developed. All these devices are some form of heat engines which are devices taking in heat from a reservoir at high temperature $T_{h}$, converting some of the heat to work and rejecting the remainder to a reservoir at lower zemperature $T_{c}$. The maximum conversion efficiency is given by Carnot relation:

$$
\eta_{b}=\frac{W_{D}}{Q_{m}}=\frac{T_{H}-T_{c}}{T_{b}}=1-\frac{T_{c}}{T_{H}}
$$

where $W_{p}$ is the heat-pressure pump work

$\eta_{\mathrm{m}}$ engine thermal efficiency

$Q_{\text {m }}$ is the heat-pressure pump heat by evaporating $R-11$.

The practical consequences of the above are that for efficiency reasons, the engine is tried to be operated with $\mathrm{T}_{\mathrm{H}}$ as high as possible and $T_{c}$ as low as possible. The requirement that heat should enter and leave the engine means that two heat exchangers are required. If the cold end is to be air cooled then the temperature $T_{c}$ can seriously limit the engine efficiency.

The working substance is not consumed in the heat engine and any temperature dependent reversible property can be used.

The heat-pump work might be calculated as:

$w_{p}=\frac{\delta \dot{m} x H}{\text { constant }} \times \eta_{H}$

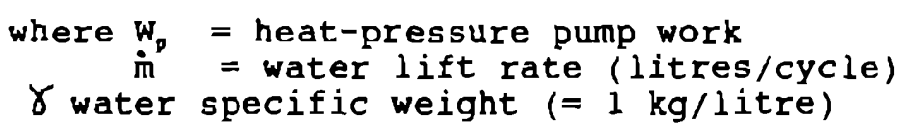

$\mathrm{H}$ difference of water level in wall and ground ( $\mathrm{m}$ )

$\eta_{H}$ Hydraulic efficiency (assumed 85 percent)

By using Equations. $I$ and 2 the $\eta_{m}$ and $w_{p}$ are calculated and plotted along with $\mathrm{m}$, in Figures 7,8 and 9 .

Figure 7 shows the effect of evaporating (high) temperature on the heat pump performance. Increase in the evaporating temperature, $T_{h}$, increases both the heat-pump work and thermal efficiency, when the cold-water temperature is considered constant a $283 \mathrm{k}$.

Figure 8 incidcates the effect of condensing (low) temperature on the heat pump performance, when the hot water is taken at a constant temperature of $323 \mathrm{~K}$. Increase in the condensing temperature, $T_{c}$, decreases both the heat-pressure pump work and the thermal efficiency.

Effect of water well level $z$, on the heat-pressure pump is indicated in Figure 9. Increase in the water level depth, $z$, increases both the heat-pressure pump work and the thermal efficiency. 


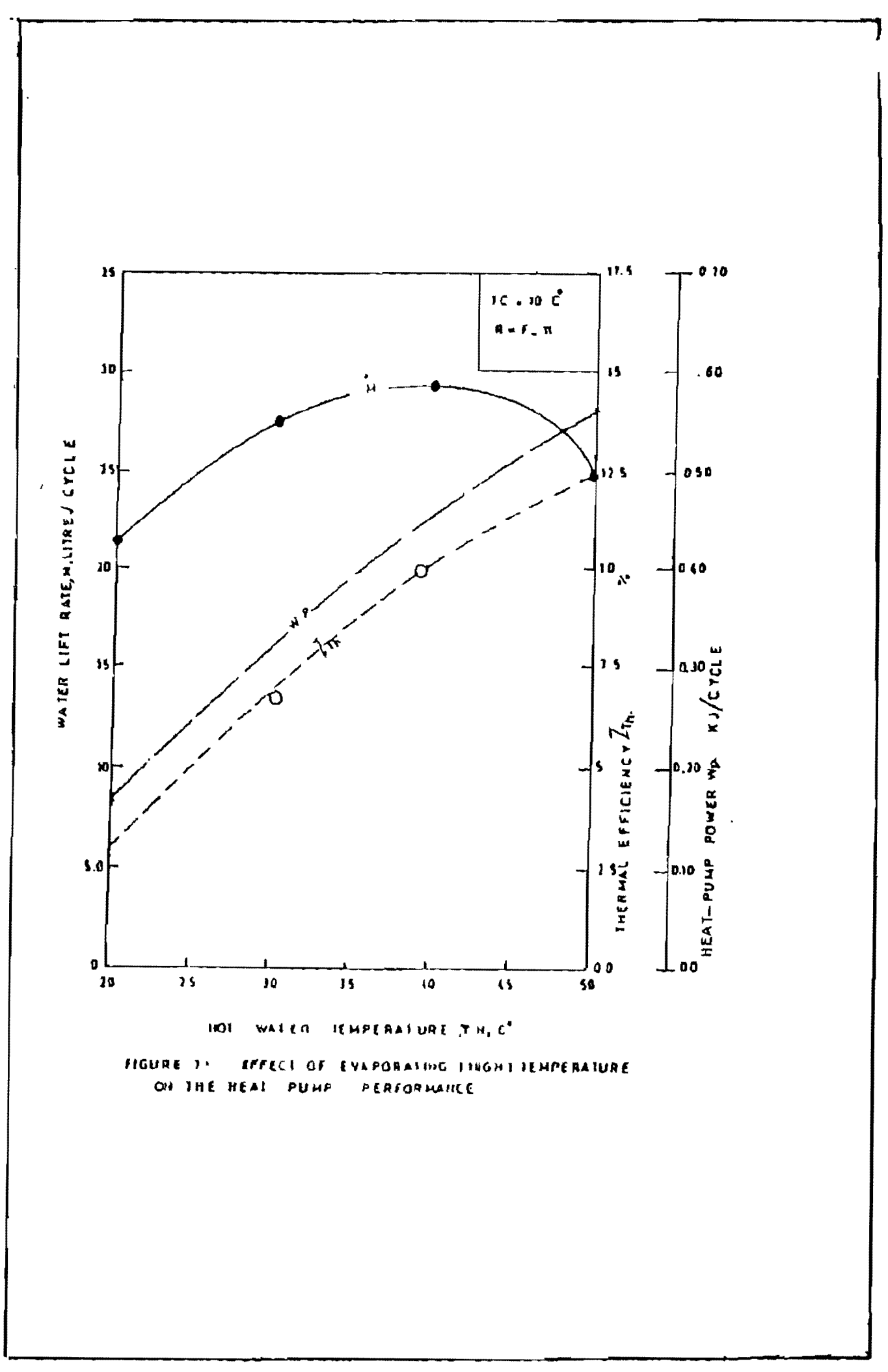


M. 117 A. A El-Hadik

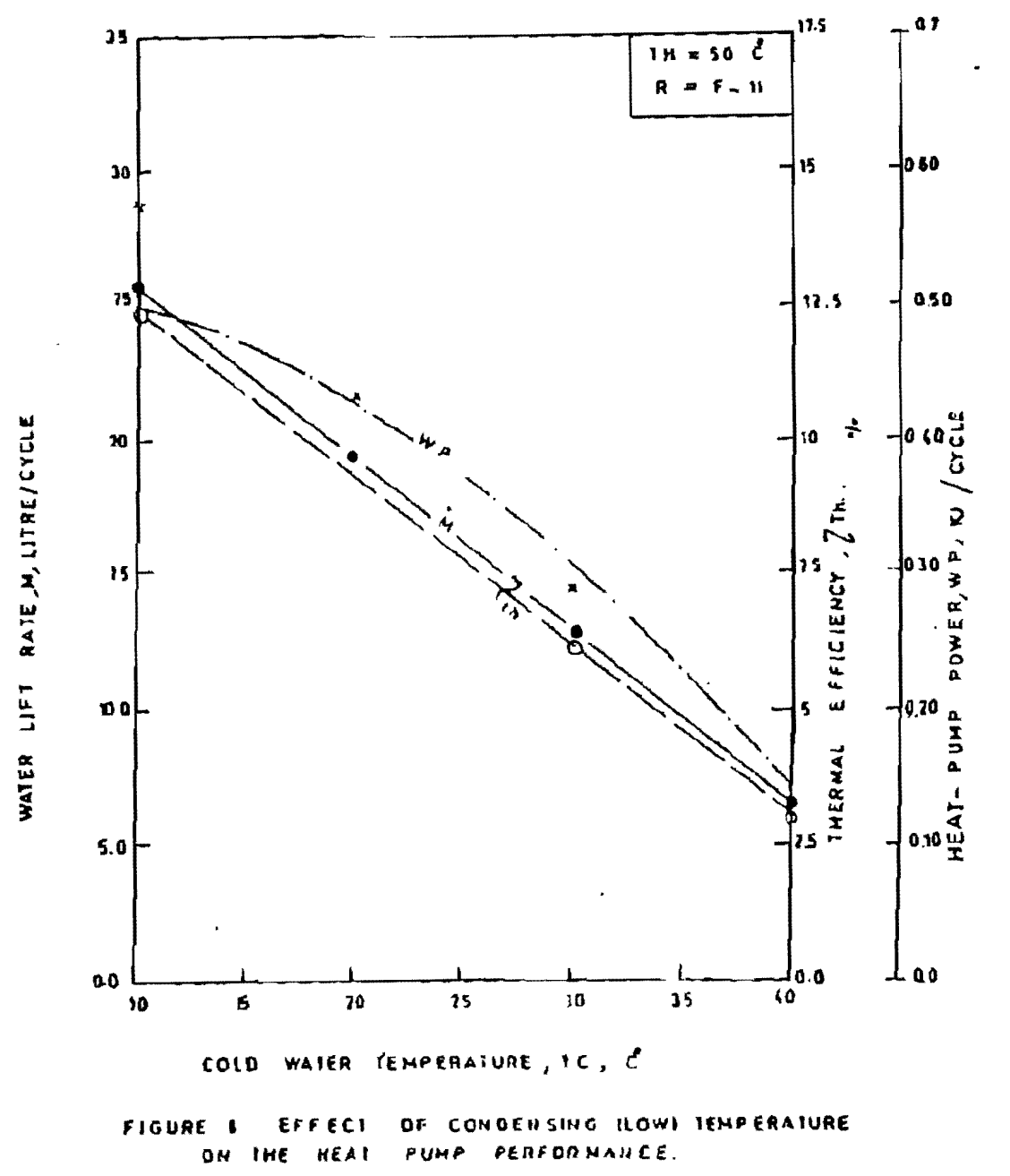




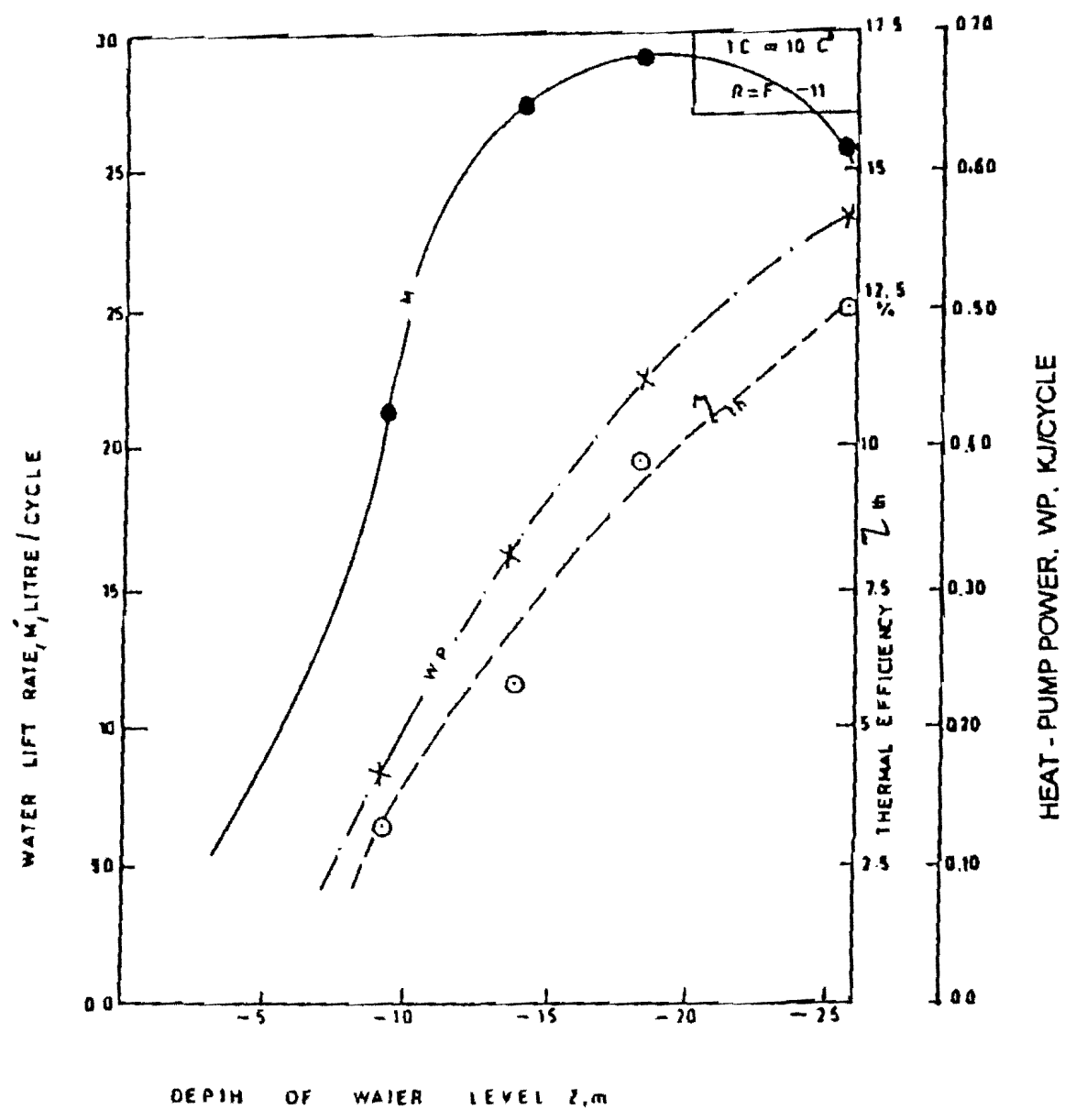

FIGUAE I EFFECI OF VIAIER IEVEL OH JHE

PUMP PEATORHAHCE 


\section{CONCLUSION :}

The new idea is found by using the sun power for producing The new idea is found by using the sun pow the Arabian desert
ground water which is important and needed for the purpose. ALS Feoron 11 is used because of its high specific volume by comparing with other refrigerants. Experimental results are plotted diagramatically as shown in Figures 7

\section{REFERENCES}

1. Coulburn, J.R. and Fearon, J., "Domestic heat pump with deep hole ground source evaporator". Applied Energy, 14 99, (1983).

Jiang, J.A. et al "Derived thermodynamic design data for heat pump systems operating on R600", J. Heat Recovery systems 3,3 (1983).

Adefila, S.s. et al., "Derived thermodynamic design data for heat pump systems operating on R717", J. Heat Recovery Systems 3, i (1983).

4. Wakao, N., and Tanisho, S., "Development of a temperature difference driven heat pump", Kagaku Kogaku Ronbunshu, g, 15 (1983).

Tanisho, S., Fahim, M.A., and Wakao, N., "Heat Transport cycle with methyl alcohol acetaldehyde chain reaction", I.J. of Energy, 2, 499 (1985).

6. Fahim, M.A., and Ford, J.D., "Energy storage using the $\mathrm{BaO}_{2} / \mathrm{BaO}$ reaction cycle", ChE J. 27,21 (1983). 